\title{
THE INFLUENCE OF ENVIRONMENT, E-WOM, AND FACILITIES ON TOURIST DECISIONS TO VISIT SAWUEK RIVER, NORTH ACEH, INDONESIA
}

\author{
Rusydi $^{1}$, Adnan ${ }^{2}$, Sutan $^{3}$, Naufal Bachri ${ }^{4}$ \\ ${ }_{1,2,3,4}$ Faculty of Economics and Business Universitas Malikussaleh
}

\author{
Correspondence Address: Jl. Tengku Chikk Ditiro. No 26 Lancang Garam. \\ Telp 0215703303 / Fax 08215733125 \\ E-mail: ${ }^{1}$ rusydi@unimal.ac.id,2adnan@unimal.ac.id, ${ }^{3}$ febriansyah.sutanf@gmail.com, \\ ${ }^{4}$ naufalbachri@unimal.ac.id
}

\begin{abstract}
This study examined the effect of the environment, E-WOM, and facilities on tourists' decision to visit Sawuek river, Indonesia. This study obtained the data by distributing questionnaires to 251 respondents selected using the non-probability approach, namely purposive sampling. The data were analyzed using the Amos SEM tool. The results showed that the environment, E-WOM, and facilities had a positive and significant effect on the decision of tourists to visit the Sawuek river in Indonesia. The tourism environment was the dominant variable influencing tourist decisions. This study had implications for the development of the concept of a river tourism environment.
\end{abstract}

Keywords: environment, E-WOM, facilities, decisions to visit.

\section{INTRODUCTION}

Sawuek river tourism is one of the exotic tourist attractions in the North Aceh district of Indonesia, which has a very special charm and uniqueness. Beautiful and natural tourist attractions invite visitors to enjoy the beauty of the Sawuek river. This place is always visited by local and regional tourists every weekend. This tourist attraction is managed by the village governments in the Kuta Makmur subdistrict of North Aceh and has become one of the most favorite tourist attractions in North Aceh (Muhammad Thaib, 2020). This tourism is expected to be an economic potential for the community and local government. This tourist attraction has not been developed to its full potential. The supporting facilities and infrastructure of the Sawuek river are inadequate, such as transportation access to the capital of North Aceh and information facilities. Toilets and prayer rooms are still very simple and do not meet the standard of facilities. The existence of supporting facilities can help development in increasing operational income at the tourist attraction.

Sustainable development can be defined as development that seeks to meet the needs of the present without compromising the ability of future generations to meet their own needs. Sustainable development can mean that the environment can support sustainable development because of its inexhaustible resources. The socio-cultural environment and natural resources are important assets for sustainable development. Besides, Word of Mouth communication is an important communication medium for promotion (Dani \& Thamrin, 2019). Electronic Word of Mouth will be an ideal medium in promoting Sawuek river tourism because it has been widely used by all groups with ease and distance limits. E-WOM is a stimulus for decision-making to use a product or service.

Facilities are one of the tangible services in creating consumer satisfaction and loyalty decisions (Parasuraman, 1988). In the tourism industry, the attractiveness of facilities is a determining 
The Influence Of Environment, E-Wom, And Facilities On Tourist Decisions To Visit Sawuek River, North Aceh, Indonesia

DOI: $10.54443 /$ ijerlas.v1i2.89

factor for consumers to choose tourist objects. Facilities in the form of equipment and physical equipment function to make it easier for guests to carry out their activities (Nicklouse et al., 2015). The attractiveness of attractive facilities can influence tourists to follow the desires currently in demand, which will attract tourists to visit and enjoy these facilities. In addition, cleanliness, smoothness, and security guarantees are also the added values that attract the attention of visiting consumers.

Based on the above phenomenon, the authors were interested in conducting a study on the decisions of local and regional tourists to visit Sawuek River tourism, North Aceh Indonesia. This study examined the influence of the environment, E-WOM communication, and facilities on the decision of tourists to visit Sawuek river tourism North Aceh, Indonesia. In addition, the authors determined the dominant factors that determine the decision to visit.

\section{LITERATURE REVIEW AND HYPOTHESES}

\subsection{Environment}

The environment is the physical, chemical, and biological conditions in the open (Prihandoyo et al. 2015), and Darsono (1995) explained that the environment is a combination of physical conditions of natural resources such as land, water, solar energy, air, minerals, flora, and fauna that grow on land and in the ocean. Hamzah (2013) mentioned that human understanding of the environment consists of two, namely (1) Anthropocentric is nature created as a provider of resources to be exploited as much as possible, and (2) Ecocentric is an environment, which is part of the natural ecosystem so that humans must respect the intrinsic value of the natural elements and pay attention to the empowerment of nature.

Witami et al. (2018) explained that the environment is an important element considered by tourist visitors. Nitisemito (2000) mentioned that the environment has several indicators, such as (1) lighting, (2) noise, (3) coloring, (4) cleanliness, (5) music, air circulation, and (6) security.

\subsection{E-Word of Mouth}

Word of mouth communication is the process of circulating information from person to person, which plays a significant role in customer purchasing decisions. Word of Mouth is based on social networks and trust. People rely on family, friends, and other social networks (Hasan et al., 2015). Consumers communicate information about the quality of products, services, including good or bad experiences experienced by consumers to other consumers through writing, sound, images, videos, or a combination of using online forums, email, search engines, and other online forms, or well-known as Electronic Word of Mouth (Firdaus and Abdullah, 2017).

Goyette et al. (2010) detailed e-WOM in three dimensions and several indicators, namely (1) Intensity, consisting of the frequency of accessing information from social networks, the frequency of interaction with users of social networking sites, and the number of reviews written by social network users. (2) Valence of opinion, consisting of positive comments from social network users and recommendations from social network users. (3) Content, consisting of product variety information, product quality information, and price information.

\subsection{Facilities}

Facilities are a form of service provided by each tourist attraction to support or support the activities of visiting tourists. Tjiptono (2004) says that facilities are physical resources that support the 
ongoing service process. Tourist facilities are supporting facilities that can create a sense of pleasure accompanied by convenience and fulfillment of the needs of tourists in enjoying the tourism products offered (Dewi, 2018). Faradisa (2016) stated that facilities provide physical equipment and convenience to consumers in carrying out activities to meet the consumer needs.

Sumayang (2004) explained that there are four types of facility dimensions, namely (1) completeness, cleanliness, and tidiness of the facilities offered by the company, (2) the condition and function of the facilities offered by the company, (3) ease of use of the facilities and (4) suitability of the facility specifications of the tools used by consumers.

\subsection{Decisions to Visit}

The decision-making process is crucial for tourism development related to various facts that influence the decision to visit a tourist destination (Rizkietal, 2018). Peter and Olson (2008) suggested that consumer decision-making is an integrated process that combines knowledge to evaluate two or more alternative behaviors and choose one of the two.

Kotler \& Keller (2012) detailed four factors that influence decisions; (1) culture, including science, belief, art, morals, customs, habits, and norms that apply to society. (2) social, such as reference groups, family, roles, and social status of all groups that directly or indirectly influence a person's attitude or behavior in the place where the person interacts; (3) personal, such as buyer's age group or work life cycle stage, economic situation, buyer's lifestyle and personality, and personal concept; (4) psychological, such as motivation, perception, knowledge, and belief.

\subsection{Hypotheses}

H1: The environment positively influenced the decision to visit the Saweuk River Water Tourism, Aceh Utara.

H2: E-Word Of Mouth positively influenced the decision to visit Saweuk river water tourism, North Aceh.

H3: Facilities positively influenced the decision to visit Saweuk River Water Tourism, North Aceh.

\section{RESEARCH METHODS}

To answer the pre-determined hypothesis, the author carried out several research approaches, such as determining the sampling technique, data collection techniques and the amount of data, and data analysis methods. This study used primary data obtained by distributing structured questionnaires to 251 respondents from 260 respondents (97\% response rate), and the data collection method used non-probability with a purposive sampling approach. This study used Multiple regression analysis to analyze primary data with the help of SPSS software.

The data measurement scale used a Likert scale (1 Strongly Disagree and 5 Strongly Agree). The questionnaire has met the requirements of validity and reliability. The environmental variable uses six indicators (Nitisemito, 2000), the e-WOM variable uses eight indicators (Goyette et al., 2010), the facility variable uses seven indicators (Sumayang, 2004), and the decision to visit variable uses four indicators (Kotler \& Keller, 2012).

\section{RESULTS AND DISCUSSIONS}

\subsection{Characteristics of Respondents}


The Influence Of Environment, E-Wom, And Facilities On Tourist Decisions To Visit Sawuek River, North Aceh, Indonesia

DOI: $10.54443 /$ ijerlas.v1i2.89

The following table describes the data on the characteristics of the respondents. The samples used were 251 local tourists 251 respondents.

Table 1. Characteristics of Respondents

\begin{tabular}{ccc}
\hline Characteristics & $\begin{array}{c}\text { Total } \\
\text { (Respondents) }\end{array}$ & $\begin{array}{c}\text { Percentage } \\
(\%)\end{array}$ \\
\hline Gender & 121 & 48 \\
Male & 130 & 52 \\
Male & & \\
Ages & 59 & 24 \\
20-30 years old & 122 & 49 \\
31-40 years old & 53 & 21 \\
41-50 years old & 17 & 7 \\
>0 years old & 159 & 63 \\
Status perkawinan & 76 & 30 \\
Married & 7 & 3 \\
Single & 9 & 4 \\
Widower & & 7 \\
Widow & 17 & 35 \\
Education & 89 & 49 \\
SMU/SMA/MA & 122 & 9 \\
Diploma & 23 & \\
Bachelor & &
\end{tabular}

The table above indicated that women (52\%) were more than men $(48 \%)$, and the respondents aged 31 to 40 years were more dominant (49\%). Local tourists who visit Sawuek river tourism were more dominant married $(63 \%)$, while the education of tourists was mainly undergraduates $(49 \%)$.

\subsection{Data Quality}

To determine the quality of the data, the authors analyzed using three approaches, consisting of normality test, multicollinearity, and heteroscedasticity. The normality test was carried out to determine whether the data distribution follows or approaches the normal distribution (Ghozali, 2011). The results showed that the data followed the diagonal line or spread around the diagonal line and can be said to meet the normality assumption and showed very significant results.

The multicollinearity test was used to see whether the independent variables in the study have a relationship or not. Table 2 indicated that all variables had a VIF $<10$ and a tolerance value of 0.1 . It showed that there was no multicollinearity between the variables studied.

Table 2. Multicollinearity Test Results

\begin{tabular}{lcc}
\hline \multirow{2}{*}{ Variables } & \multicolumn{2}{c}{ Collinearity Statistics } \\
\cline { 2 - 3 } & Tolerance & VIF \\
\hline Environemt $\left(\mathrm{X}_{1}\right)$ & 0,582 & 1,768 \\
e-WOM $\left(\mathrm{X}_{2}\right)$ & 0,438 & 2,421 \\
Facilities $\left(\mathrm{X}_{3}\right)$ & 0,622 & 1,579 \\
\hline
\end{tabular}


In this study, there was no heteroscedasticity in the regression model, so it was feasible to predict the influence of the environment, e-WOM, and facilities on the decision to visit Sawuek river tourism in North Aceh.

\subsection{Hypotheses Tests}

Testing through multiple linear regression was conducted to analyze the influence of environment, e-WOM, and facilities on the decision to visit with the help of SPSS. The results of the analysis can be seen in the table below:

Table 3. T-statistics Values

\begin{tabular}{cccc}
\hline Effects of Variables & $\begin{array}{c}\text { t- } \\
\text { statistics } \\
\text { Values }\end{array}$ & $\begin{array}{c}\text { Signific } \\
\text { ance Values }\end{array}$ \\
\hline $\begin{array}{c}\text { Environ } \\
\text { ment } \\
\text { E- }\end{array}$ & Decisions to Visit & 4,518 & 0,000 \\
$\begin{array}{c}\text { WOM } \\
\text { Facilitie }\end{array}$ & Decisions to Visit & 4,191 & 0,002 \\
S & Decisions to Visit & 0,370 & 0,213 \\
\hline
\end{tabular}

\subsection{The Influence of Environment on Decisions to Visit}

The first hypothesis test results showed that the results of the regression calculation indicated that the environment had a significant effect on the decision to visit where the $t$-count value was 4.518 or higher than the $\mathrm{t}$-table value ( $\mathrm{df}=\mathrm{n}-\mathrm{k})$ at $\mathrm{n}=248$, which was 1.65 at the $5 \%$ level. Also, the significant value was 0.000 or lower than $=0.05$. So, these results indicated that the environment had a positive and significant effect on the decision to visit Sawuek river tourism in North Aceh.

The results of this study were in line with the study of Prihandoyo (2015), Amalia (2017), and Olivia et al. (2015), which stated that the environment had a positive effect on tourist decisions. Local tourists like the natural panorama of the Sawuek river, which is still natural or not much human touch. In addition, the air in the Sawuek river area is still very cool and fresh, and there is no air pollution. Furthermore, the water feels cold and clean from environmental pollution.

\subsection{The Effect of e-WOM on Decisions to Visit}

The second hypothesis test results showed that e-WOM had a significant effect on decisions to visit, where the $\mathrm{t}$-count value was 4.191 or higher than the $\mathrm{t}$-table value $(\mathrm{df}=\mathrm{n}$ k) at $\mathrm{n}=248$, which was 1.65 at the $5 \%$ level with the significant value 0.002 or lower than $=0.05$. These results indicated that e-WOM communication significantly influenced the decision to visit Sawuek river tourism.

The results of this study were in line with the Taharu study (2019), which claimed that e-WOM communication significantly influenced purchasing decisions. E-WOM communication is very effective in spreading among young and adult tourists. This communication is one element of the loyalty of tourists to the Sawuek river area, North Aceh.

\subsection{The Influence of Facilities on Decisions to Visit}


The Influence Of Environment, E-Wom, And Facilities On Tourist Decisions To Visit Sawuek River, North Aceh, Indonesia

DOI: $10.54443 /$ ijerlas.v1i2.89

The third hypothesis indicated that the facility did not significantly influence the decision to visit where the $\mathrm{t}$-count value was 0.370 or lower than the $\mathrm{t}$-table value $(\mathrm{df}=\mathrm{n}-\mathrm{k})$ at $n=248$, which was 1.65 at the $5 \%$ level, and the significant value was 0.213 or higher than $=0.05$. These results indicated that the facilities did not influence the decision to visit the Sawuek river tourism.

The results were not in line with the results study by Setiadi (2018), which stated that facilities are a substantial element in improving tourist visiting decisions. In this case, the facilities provided by the Village Government did not meet existing standards yet, such as the unavailability of a large parking area, frequent traffic jams, and the unavailability of sufficient information about Sawuek river tourism.

\section{CONCLUSIONS AND RECOMMENDATIONS}

\subsection{Conclusions}

This study examined the influence of the environment, e-WOM, and tourist facilities on the decision to visit of local tourists to the Sawuek river, North Aceh. Environment and e-WOM had a significant effect on the decision to visit of local tourists to the Sawuek river. Meanwhile, tourist facilities did not influence the decision to visit of local tourists to the Sawuek river.

\subsection{Recomendations}

In this study, three predictor variables used were the environment, e-WOM, and tourist facilities. Further studies should use more specific environmental variables, such as the cultural environment and the social environment. The sample used was limited to local tourists who come from Aceh Province only. Further studies were expected to expand the samples, such as from regional and foreign tourists.

\subsection{Implication}

This research had implications for the development of environmental concepts, especially in the tourism industry in remote areas. Also, the results can contribute to the provincial, city, and Village Governments for tourism development. The Government should build adequate infrastructure without destroying the existing environment.

\subsection{Acknowledgments}

In carrying out this study, many parties have helped in delivering information/data to the provision of funds and other support. On this occasion, the authors would like to thank the Chancellor of the Malikussaleh University, Mr. Dean of the Faculty of Economics and Business, Mr. Chairman of the Institute for Research and Community Service, to the youth and tourism offices of North Aceh and Geuchik Gampong Sawuek and the local community.

\section{REFERENCES}

Abdullah, T dan Firdaus, T (2017). E-WoM: Pengaruhnya terhadap Keputusan Pembelian Tamu Restoran di Bandung Utara. Tourism and Hospitality Essential (THE) Journal, Vol. 7 No. 1. Abubakar Rusydi ( 2018). Manajemen pemasaran. Bandung, CV. Alfabeta. 
Amalia, T., Ekwarso, H., \& Taryono (2017). Pengaruh Lingkungan Fisik Terhadap Tingkat Kunjungan Wisatawan Di Museum Daerah Sang Nila Utama Kota Pekanbaru. JOM Fekon, Vol. 4 No.1 pp. 1202-1214

Asrianda, Khalil, M., Asnawi, \& Bachri, N. (2020). Fuzzy AHP Model in Influencing the Decision to Visit a Coffee Shop. International Journal of Psychosocial Rehabilitation, Vol. 24, No. 2 , pp.372-381.

Ayuningtyas Sri Athika, Fauzi Dh Ahmad, Nur alam Perwangsa Inggang (2019). Pengaruh terpaan Media Sosial Instagram terhadap Keputusan Berkunjung dengan Citra Destinasi sebagai Variabel Mediasi. Jurnal Administrasi Bisnis (JAB), Vol.68 No.1.

Bachri, Naufal. (2019). Statistik Dasar untuk Bisnis: Teori, Pendekatan, dan Contoh Kasusnya. Sukabumi: CV Jejak

Bataineh, A.Q. (2015). The Impact of Perceived-WOM on Purchase Intention: The Mediating Role of Corporate Image. International Journal of Marketing Studies, Vol. 7, No. 1.

Hamzah, S. (2013). Pendidikan Lingkungan: Sekelumit Wawasan Pengantar Bandung: Refika Aditama.

Daryanto (2011). Manajemen Pemasaran. Bandung: PT. Sarana Tutorial Nurani Sejahtera.

Darsono, Valentinus (1995). Pengantar Ilmu Lingkungan. Yogyakarta. Penerbit: Universitas Atma Jaya.

Deimling, G.T., Smergia, V.L., \& Schaefer, M.L. (2001). The Impact of Family Environment and Decision-Making Satisfaction on Caregiver Depression: A Path Analytic Model. Journal of Aging and Health. https://doi.org/10.1177/089826430101300103

Dionisius Hendry Gunawan (2019). Pengaruh Lingkungan Terhadap Keputusan Pembelian Di Pasar Landungsari, Jurnal AGREGAT,

Faradisa Isti (2016). Analisis Pengaruh Variasi Produk, Fasilitas, Dan Kualitas Pelayanan Terhadap Minat Beli Ulang Konsumen Pada Indonesian Coffeeshop Semarang (Icos Cafe).Vol.2 No.2.

Fitri A., Bachri, N., \& Abubakar, R. (2018). Pengaruh Kemampuan Inovasi Terhadap Keputusan Pembelian Roti Bantal Melalui Daya Tarik Produk dan Daya Tarik Promosi Sebagai Variabel Mediasi di Kota Banda Aceh. Jurnal Manajemen Indonesia (J-MID), Vol.2 No.1 pp. 31-47

Fotis, J.N. (2015). The Use of Social Media and its impact on Consumer Behaviour: The Context of Holiday Travel. Disertasi. Boston: Bournemouth University.

Goyette, I., Ricard, L., Bergeron, J., Marticotte, F. (2010). e-WOM scale: Word-of-Mouth measurement scale for e-service context, Canadian Journal of Administrative Sciences, 27(1), $5-23$.

Hastuti Dwi, Latief Abdul Donny, Ibrahim dan Jalaluddin (2016). Strategi meningkatkan kunjungan wisatawan ke Provinsi Aceh. Jurnal Ekonomi Manajemen dan Akuntansi, Vol.2 No.2.

Hasan Ali \& Setianingtyas Widiati Niken (2015). Pengaruh Electronic Word Of Mouth pada Media Sosial Facebook terhadap Keputusan berkunjung ke desa wisata Nglanggeran Gunung Kidul. Jurnal Media Wisata,Vol. 13 No 1.

https : //acehutarakab.bps.go.id /publikasihtml.

https://tekno.kompas.com/read/2019/02/05/11080097/facebook-jadi-medsos-paling digemari- diIndonesia?page $=1$. 
The Influence Of Environment, E-Wom, And Facilities On Tourist Decisions To Visit Sawuek River, North Aceh, Indonesia

DOI: $10.54443 /$ ijerlas.v1i2.89

Kotler, Philip and Gary Amstrong (2012), Prinsip-prinsip Pemasaran. Edisi 13 Jilid 1. Jakarta: Erlangga.

Lopes, Sergio Dominique Ferreira (2011). Destination Image: Origins, Developments and Implications. Journal of Pasos Revista de Turismo y Patrimonio Cultural, Vol. 9 No 2. pp. 305-315.

Mulfachriza, M., Bachri, N., \& Biby, S. (2021). Pengaruh Bauran Pemasaran dan Kualitas Layanan Terhadap Keputusan Konsumen Memiliki Kartu Kredit Bank BRI Dengan Gaya Hidup Sebagai Variabel Moderating. Jurnal Manajemen Indonesia (J-MID), Vol.6 No.1 pp. 70-79.

Olivia, D.F., Saifi, M., Endang, M.G. (2015). Pengaruh Faktor-Faktor Lingkungan Eksternal Terhadap Keputusan Berkunjung Wisatawan (Survey pada Wisatawan Museum Angkut Batu Jawa Timur). Jurnal Administrasi Bisnis (JAB), Vol 21 No.1 pp. 1-10.

Peter, J. Paul and Jerry C. Olson. 2008. Consumer Behavior : Perilaku Konsumen dan Strategi Pemasaran. Cetakan Pertama Edisi Bahasa Indonesia. Penerbit Erlangga. Jakarta

Priansa Juni Donni (2016). Pengaruh Electronic Word Of Mouth dan Persepsi nilai terhadap Keputusan konsumen untuk berbelanja Online diLazada. Jurnal Ecodemica,Vol. IV No.1.

Rita Hutomo, Karyana., N. (2013). Electronic Word Of Mouth (E-Wom) Foursquare: The New Social Media. Binus Business Review, Vol. 4.

Setiadi, Bahrul (2018). Pengaruh Harga, Lokasi, dan Fasilitas Wisata Terhadap Keputusan Berkunjung Wisatawan (Studi pada Objek Wisata Pantai Tiga Warna di Kabupaten Malang). Jurnal Ilmiah Mahasiswa FEB Unibraw, Vol.6 No. 1.

Syamni, G., \& Bachri, N. (2012). Bisnis Hijau dan Faktor-Faktor yang Mendorongnya: Suatu Kajian Literatur. Jurnal Ekonomi, Manajemen dan Akuntansi, Vol.1, No.1.

Taharu, R. V., Barusman, A. R. P., \& Saptarini, V. (2019). Pengaruh e-Wom dan Review Produk pada Market Place Shopee Terhadap Keputusan Pembelian Pakaian Jadi Di Bandar Lampung. Jurnal Visionist, Vol.8 No.1 pp. 40-47.

Qabiluddin, Abubakar, R., \& Bachri, N. (2018). Analisis Pengaruh Bauran Pemasaran Jasa Terhadap Keputusan Pendengar Radio Dakwah Aceh Utara Dan Lhokseumawe. Jurnal Manajemen Indonesia (J-MID), Vol.2 No.1 pp. 118-123.

Witami, R.W., Rosita, Sri Marhanah (2018). Journal of Indonesian Tourism, Hospitality and Recreation, Vol. 1, No.1 pp. 69-79 